\title{
Advanced Fuel Cell Membranes Based on Heteropolyacids
}

\author{
John A. Turner and John Pern \\ Hydrogen and Electricity, Systems and Infrastructure Group+ \\ National Renewable Energy Laboratory \\ Golden, CO 80401-3393
}

Andrew M. Herring, ${ }^{*}$ Steven F. Dec
Fanqin Meng,

Department of Chemical Engineering* and

Department of Chemistry and Geochemistry ${ }^{x}$

Colorado School of Mines

Golden, CO 80401-1887

May 24, 2005

Project ID \#

This presentation does not contain any proprietary or confidential information FCP3 


\section{Overview}

\section{Timeline}

- Project start date: FY 2005

- Project end date: tbd

- Percent complete: tbd

Budget

- Total project funding

- DOE share: \$150k
Barriers

- Barriers addressed

- Thermal, Air and Water Management

- Cost.

- Durability

Partners

- 3M

- Colorado School of Mines. 


\section{Objectives and Approach}

- To demonstrate dry inlet gas operation of HPA-based PEMs in FC at $\mathrm{T} \geq 80^{\circ} \mathrm{C}$.

- Synthesize and characterize selected "saturated" and lacunary heteropoly acids (HPA) that have high potential for the fabrication of FC membranes

- Fabricate heteropoly acid-based proton exchange membrane (PEM)

- Mechanically strong

- Stable operation

- Low-cost

- Higher temperature/low humidity operation. 


\section{Example Structures of Three HPAs}

1. Keggin

(saturated)

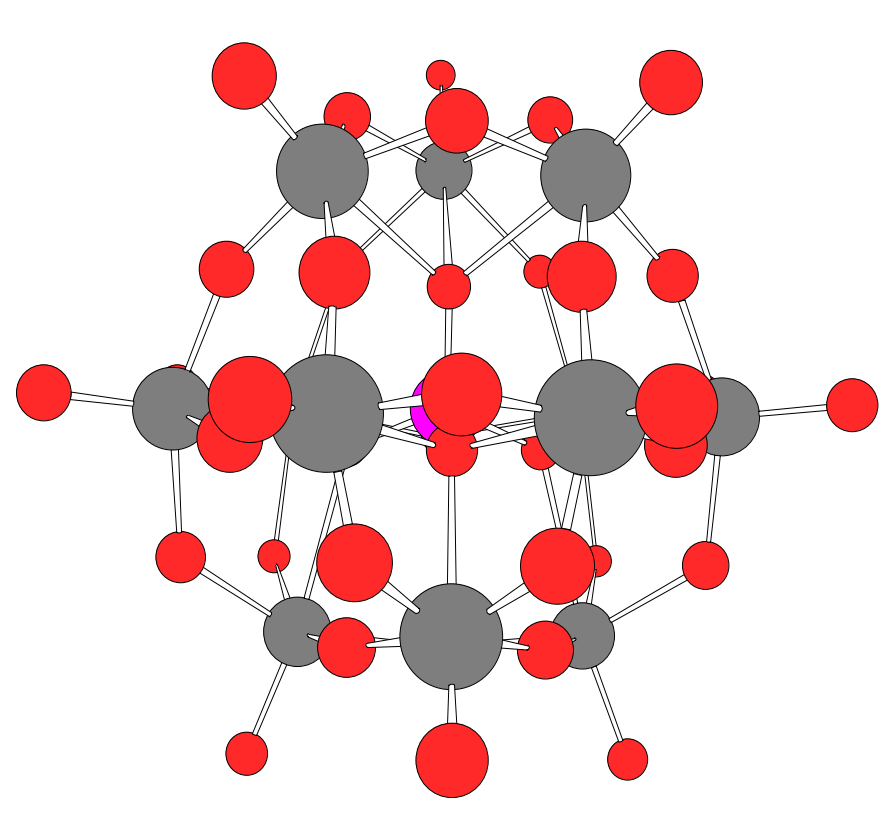

$\left[\mathrm{SiW}_{12} \mathrm{O}_{40}\right]^{4-}$

$\mathrm{H}_{4} \mathrm{SiW}_{12} \mathrm{O}_{40}-22 \mathrm{H}_{2} \mathrm{O}$

(12-HSiW)
2. Lacunary

(vacant sites)

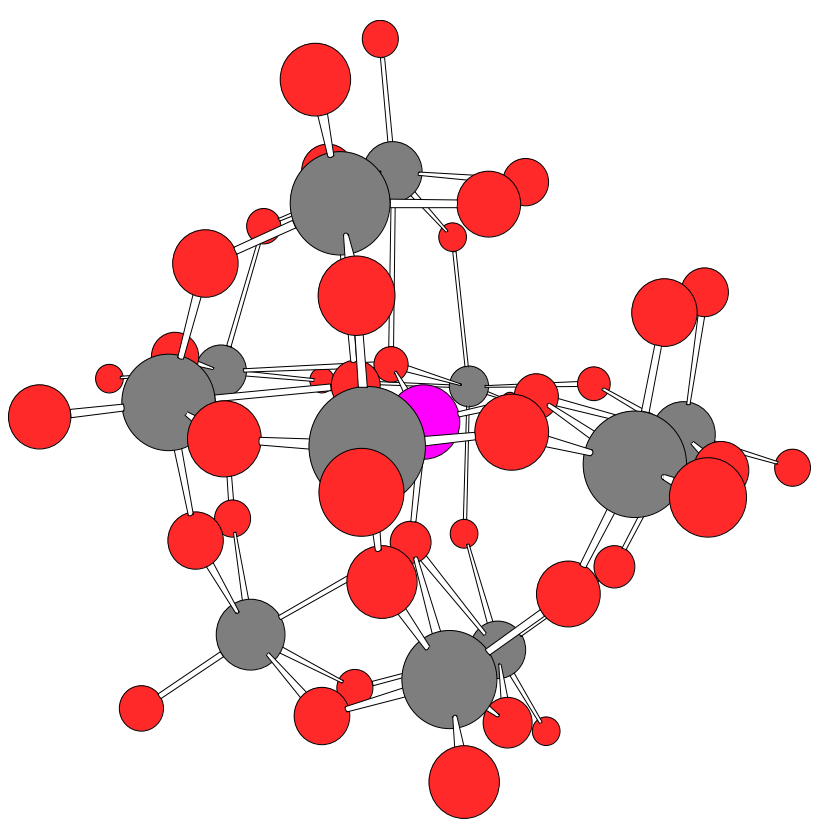

$\left[\mathrm{SiW}_{11} \mathrm{O}_{39}\right]^{8-}$

$\mathrm{H}_{8} \mathrm{SiW}_{11} \mathrm{O}_{39}-26 \mathrm{H}_{2} \mathrm{O}$

(11-HSiW)
3. Dawson

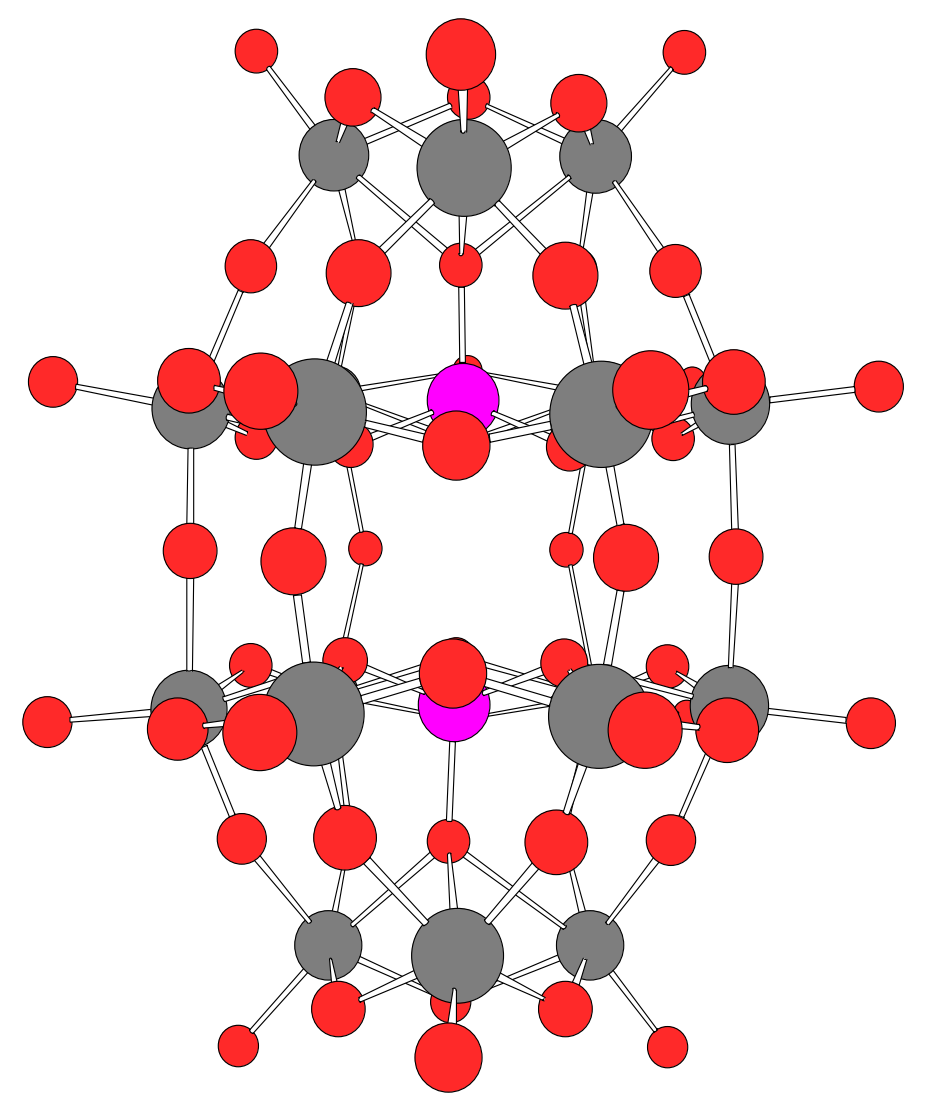

$\left[\mathrm{P}_{2} \mathrm{~W}_{18} \mathrm{O}_{62}\right]^{6-}$

$\mathrm{H}_{6} \mathrm{P}_{2} \mathrm{~W}_{18} \mathrm{O}_{62}-\mathrm{xH}_{2} \mathrm{O}$

(18-HP2W) 4 


\section{TGA for Various HPAs (after heating to $110^{\circ} \mathrm{C}$ )}

\begin{tabular}{|c|c|c|c|c|c|c|c|}
\hline \multirow[t]{2}{*}{ HPA } & \multicolumn{2}{|c|}{$\begin{array}{c}\text { Water of } \\
\text { crystallization }\end{array}$} & \multicolumn{2}{|c|}{$\begin{array}{c}\text { Secondary structure } \\
\text { water }\end{array}$} & \multicolumn{2}{|c|}{ Neutralization } & \multirow{2}{*}{$\begin{array}{l}\text { Decomp. } \\
\text { Temp. }{ }^{\circ} \mathrm{C}\end{array}$} \\
\hline & $\begin{array}{l}\text { Equiv. } \\
\mathrm{H}_{2} \mathrm{O}\end{array}$ & $\begin{array}{c}\text { Temp. }^{\circ} \\
\text { C }\end{array}$ & $\begin{array}{l}\text { Equiv. } \\
\mathrm{H}_{2} \mathrm{O}\end{array}$ & Temp. ${ }^{\circ} \mathrm{C}$ & $\begin{array}{l}\text { Equiv. } \\
\mathrm{H}_{2} \mathrm{O}\end{array}$ & Temp. ${ }^{\circ} \mathrm{C}$ & \\
\hline $\mathrm{H}_{3} \mathrm{PW}_{12} \mathrm{O}_{40}$ & 1 & 50 & 6 & 164 & 1 & 482 & 589 \\
\hline $\mathrm{H}_{8} \mathrm{SiW}_{11} \mathrm{O}_{39}$ & 2 & 60 & 7 & 152 & 6 & 410 & 611 \\
\hline $\mathrm{H}_{6} \mathrm{SiV}_{2} \mathrm{~W}_{10} \mathrm{O}_{40}$ & & & 6 & 129 & 2 & 250 & 471 \\
\hline $\mathrm{H}_{8} \mathrm{SiV}_{3} \mathrm{~W}_{10} \mathrm{O}_{40}$ & & & 7 & 183 & & & 477 \\
\hline $\mathrm{H}_{6} \mathrm{ZnW}_{12} \mathrm{O}_{40}$ & 10 & 90 & 10 & 160 & 2 & 480 & \\
\hline $\mathrm{H}_{6} \mathrm{P}_{2} \mathrm{~W}_{18} \mathrm{O}_{62}$ & & & 4 & 114 & 3 & 290 & $>600$ \\
\hline$\overline{\mathrm{Na}_{\mathrm{x}} \mathrm{H}_{\mathrm{y}} \mathrm{P}_{2} \mathrm{~W}_{18} \mathrm{O}_{62}}$ & 7 & 60 & 5 & 114 & & & 597 \\
\hline $\mathrm{H}_{6} \mathrm{As}_{2} \mathrm{~W}_{21} \mathrm{O}_{69}$ & & & 12 & 129 & 4 & 430 & 430 \\
\hline & & & 2 & 316 & & & \\
\hline$\overline{\mathrm{H}_{6} \mathrm{P}_{2} \mathrm{~W}_{21} \mathrm{O}_{71}}$ & & & 4 & 170 & 3 & 350 & 590 \\
\hline $\mathrm{H}_{21} \mathrm{~B}_{3} \mathrm{~W}_{39} \mathrm{O}_{132}$ & 17 & 59 & 7 & 203 & 4 & 358 & 405 \\
\hline
\end{tabular}




\section{Proton Diffusion Coefficients of HPAs Determined by PF-NMR}

\begin{tabular}{|c|c|c|c|c|c|c|}
\hline HPA & $\begin{array}{c}\text { Max } \\
\text { diffusion } \\
\text { coefficent } \mathrm{x} \\
10^{-6} \mathrm{~cm}^{2} \mathrm{~s}^{-1}\end{array}$ & $\begin{array}{l}\text { Temperature of } \\
\text { maximum } \mathrm{D},{ }^{\circ} \mathrm{C}\end{array}$ & $\begin{array}{c}\text { Ea } \\
\text { before } \\
\text { Max T, } \\
\mathrm{kJ} \mathrm{mol}^{-1}\end{array}$ & $\begin{array}{l}\text { IR H- } \\
\text { bond } \\
\text { strength }\end{array}$ & \multicolumn{2}{|c|}{ Secondary structure } \\
\hline 12-HPW & 25 & 117 & 13 & 20 & $\mathrm{H}^{+}\left(\mathrm{H}_{2} \mathrm{O}\right)_{\mathrm{x}}$ & cubic \\
\hline 12-HSiW & 30 & 130 & 20 & 40 & $\mathrm{H}^{+}\left(\mathrm{H}_{2} \mathrm{O}\right)_{\mathrm{x}}$ & cubic \\
\hline $12-\mathrm{HZnW}$ & 2 & 108 & 27 & 30 & $\mathrm{H}_{5} \mathrm{O}_{2}^{+}, \mathrm{OH}$ & cubic \\
\hline 12-HGeW & 0.7 & 90 & 35 & & & cubic \\
\hline 11-SiW11 & 3 & 108 & 6 & 35 & $\mathrm{H}_{5} \mathrm{O}_{2}^{+}, \mathrm{OH}$ & cubic \\
\hline 39-HB3W & 7 & 128 & 8 & 18 & $\mathrm{H}^{+}\left(\mathrm{H}_{2} \mathrm{O}\right)_{\mathrm{x}}$ & sheets \\
\hline 18-HP2W & 1.2 & $>150$ & 20 & 20 & $\mathrm{H}_{3} \mathrm{O}^{+}$ & triclinic \\
\hline 21-HAs2W & 3.7 & $>150$ & 18 & 18 & $\mathrm{H}_{5} \mathrm{O}_{2}^{+}$ & \\
\hline $21-\mathrm{H}_{2} \mathrm{Rb}_{4} \mathrm{As} 2 \mathrm{~W}$ & 30 & 25 & - & & $\mathrm{H}^{+}\left(\mathrm{H}_{2} \mathrm{O}\right)_{\mathrm{x}}$ & channels \\
\hline $21-\mathrm{HP} 2 \mathrm{~W}$ & 2.3 & 110 & 24 & 27 & $\mathrm{H}_{3} \mathrm{O}^{+}$ & \\
\hline
\end{tabular}




\section{Polarization curves of PEM made of 12- HPW physically blended in PVDF-HFP}

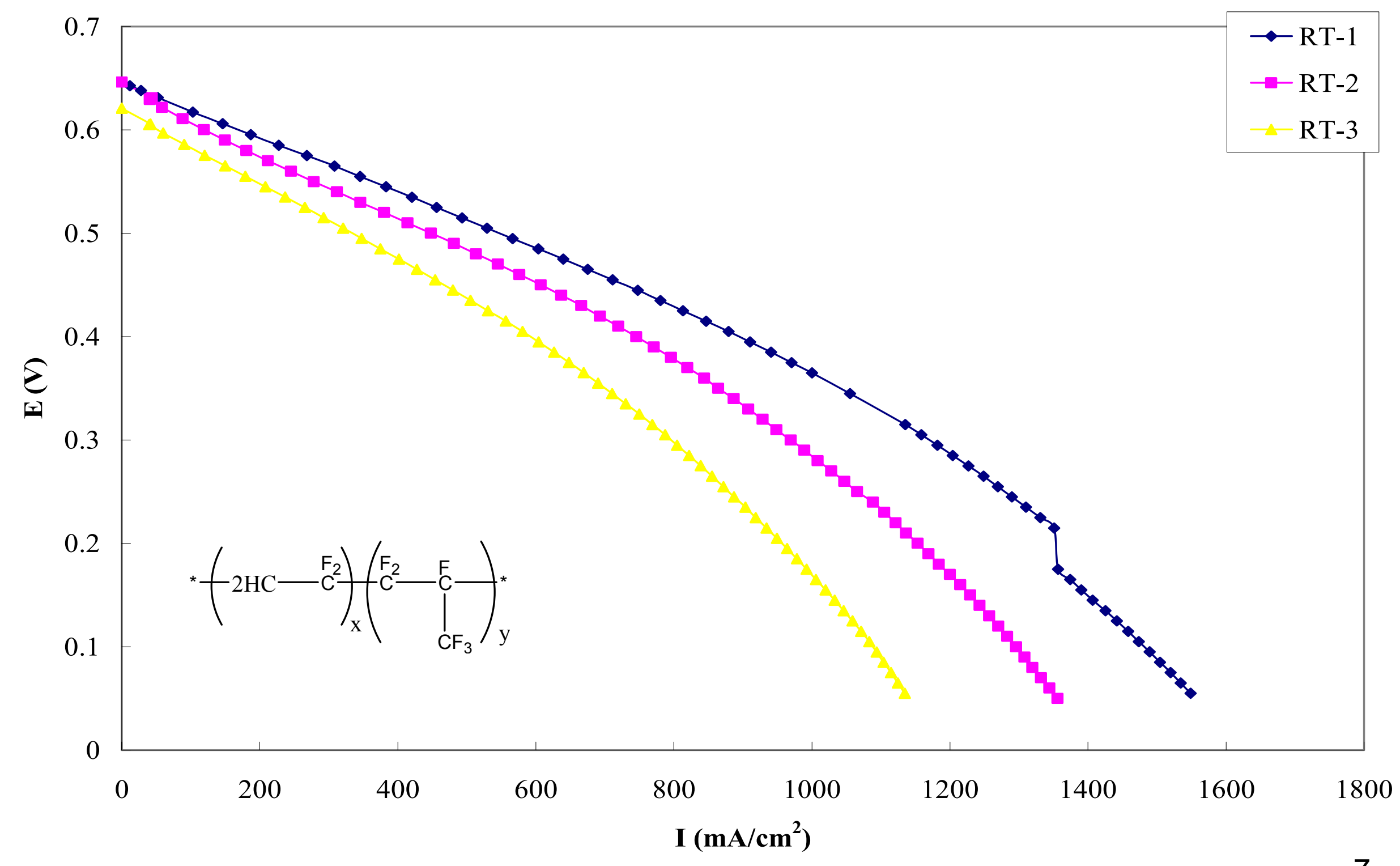




\section{Diffusion coefficient data for HPA doped Nafion ${ }^{\circledR} 112$ protons}

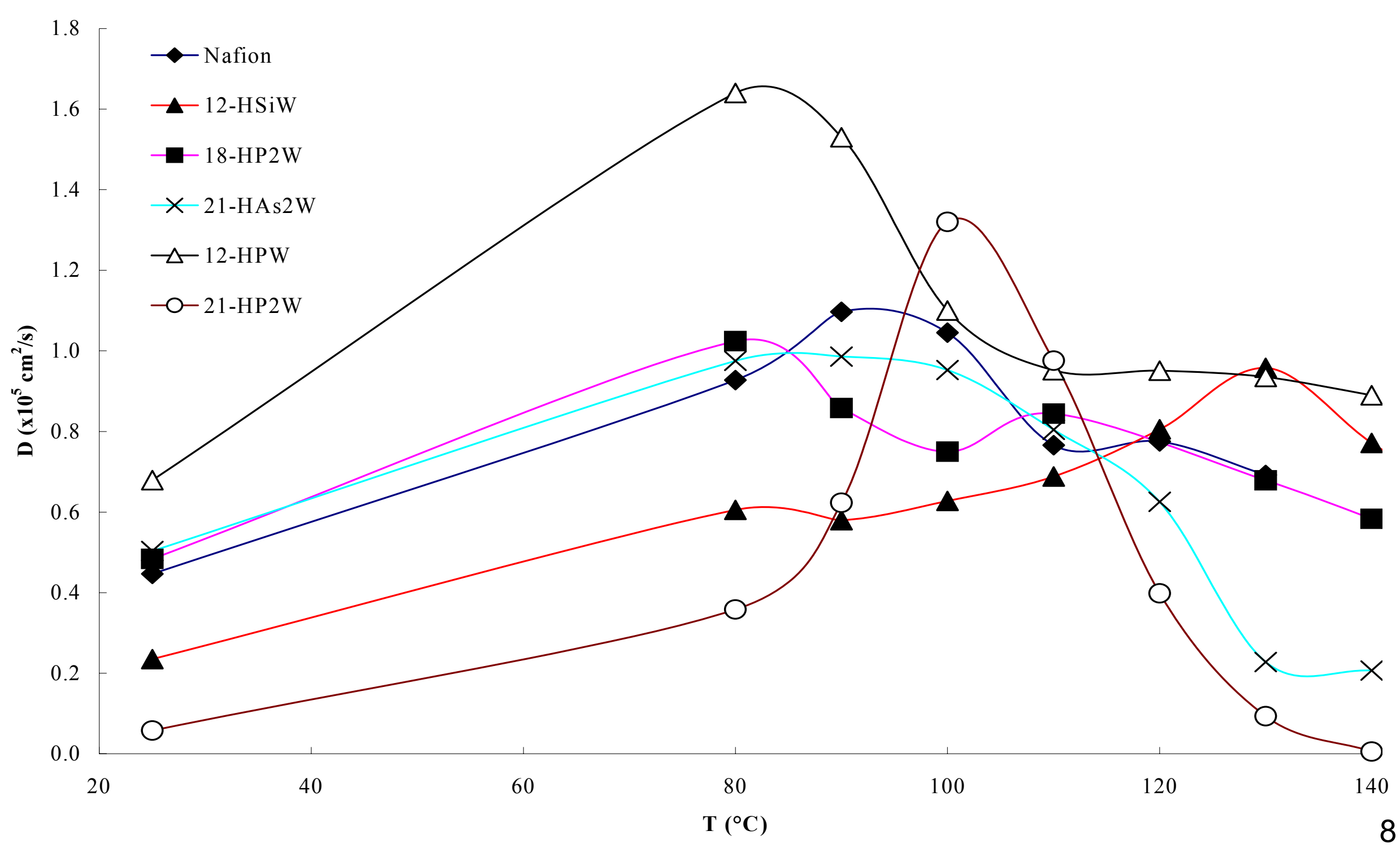




\section{Polarization curves comparing Nafion and HPA-doped Nafion ${ }^{\circledR}$}

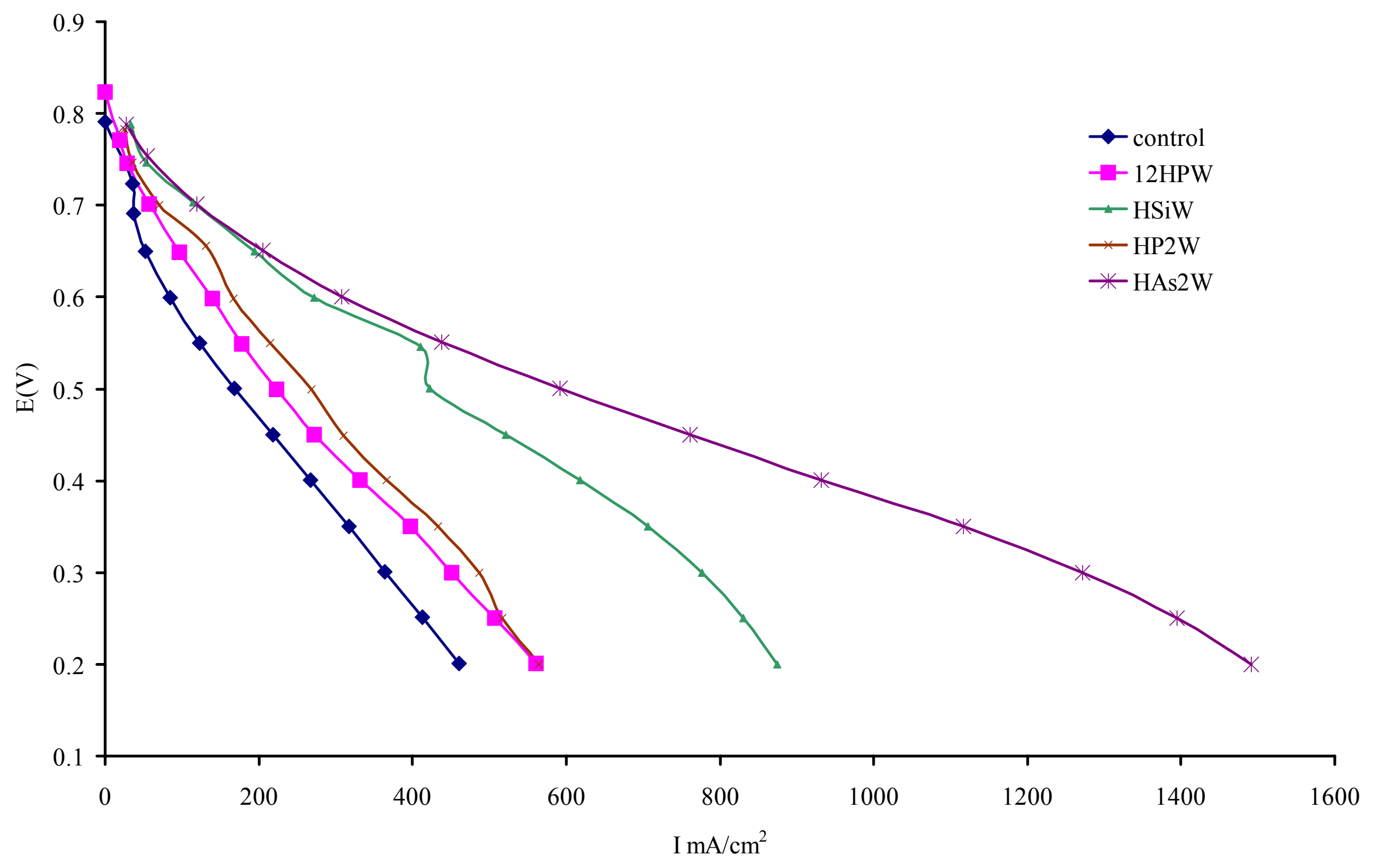

$120{ }^{\circ} \mathrm{C}$ Nafion ${ }^{\circledR} 112,25 \% \mathrm{RH}$, No ionomer in electrode (ELAT) $0.5 \mathrm{mg} / \mathrm{cm}^{2} 20 \% \mathrm{Pt}$ on carbon. 


\section{Strategies for Immobilizing HPAs}

A. Bonding Approaches:

1. Covalent bonding directly to a polymeric matrix

2. Covalent bonding to oxide nanoparticles, which can further bond covalently to, or embed physically in a polymeric matrix

3. Direct embedding in a polymeric matrix

B. Modification of Lacunary HPAs:

1. By bonding with functional silanes that can then cross-linked or be polymerized

C. Fabrication Approaches:

1. Sol gel method

2. Immobilized via silylation onto supporting particles

3. Simple blending

D. Polymeric Matrix:

1. Organic

2. Inorganic

3. organic-inorganic hybrid

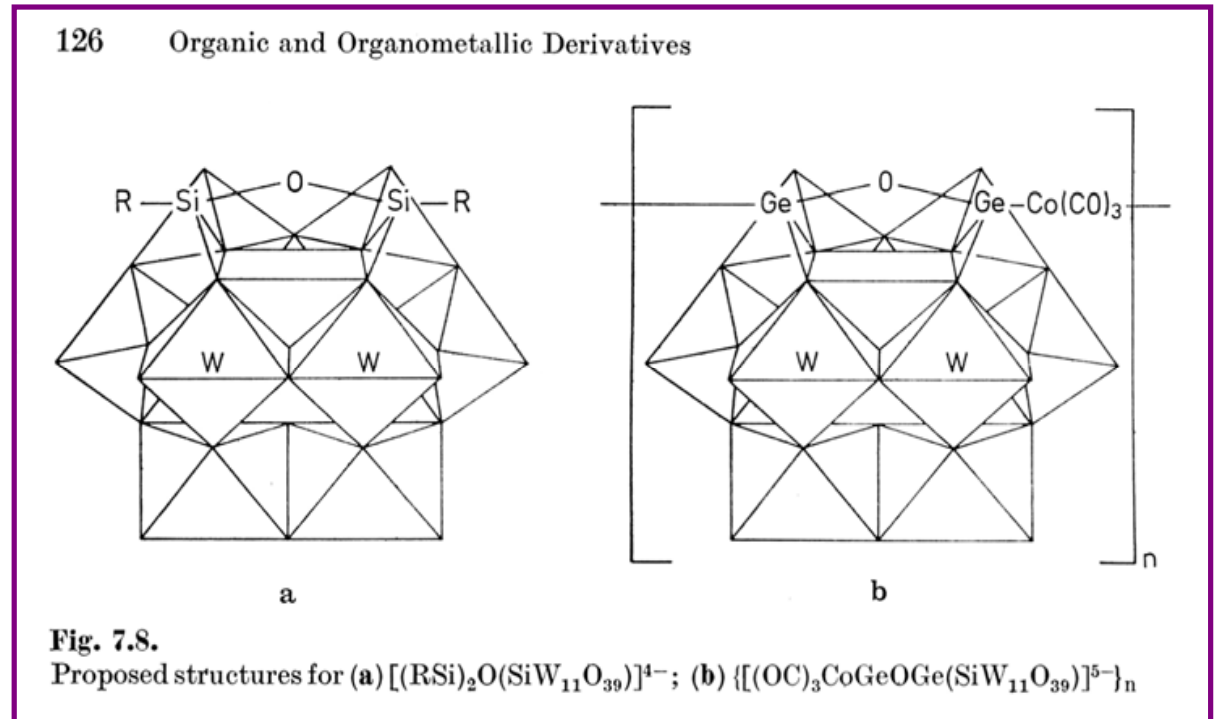




\section{Multiple Approaches for Making HPA-based Hybrid PEM}

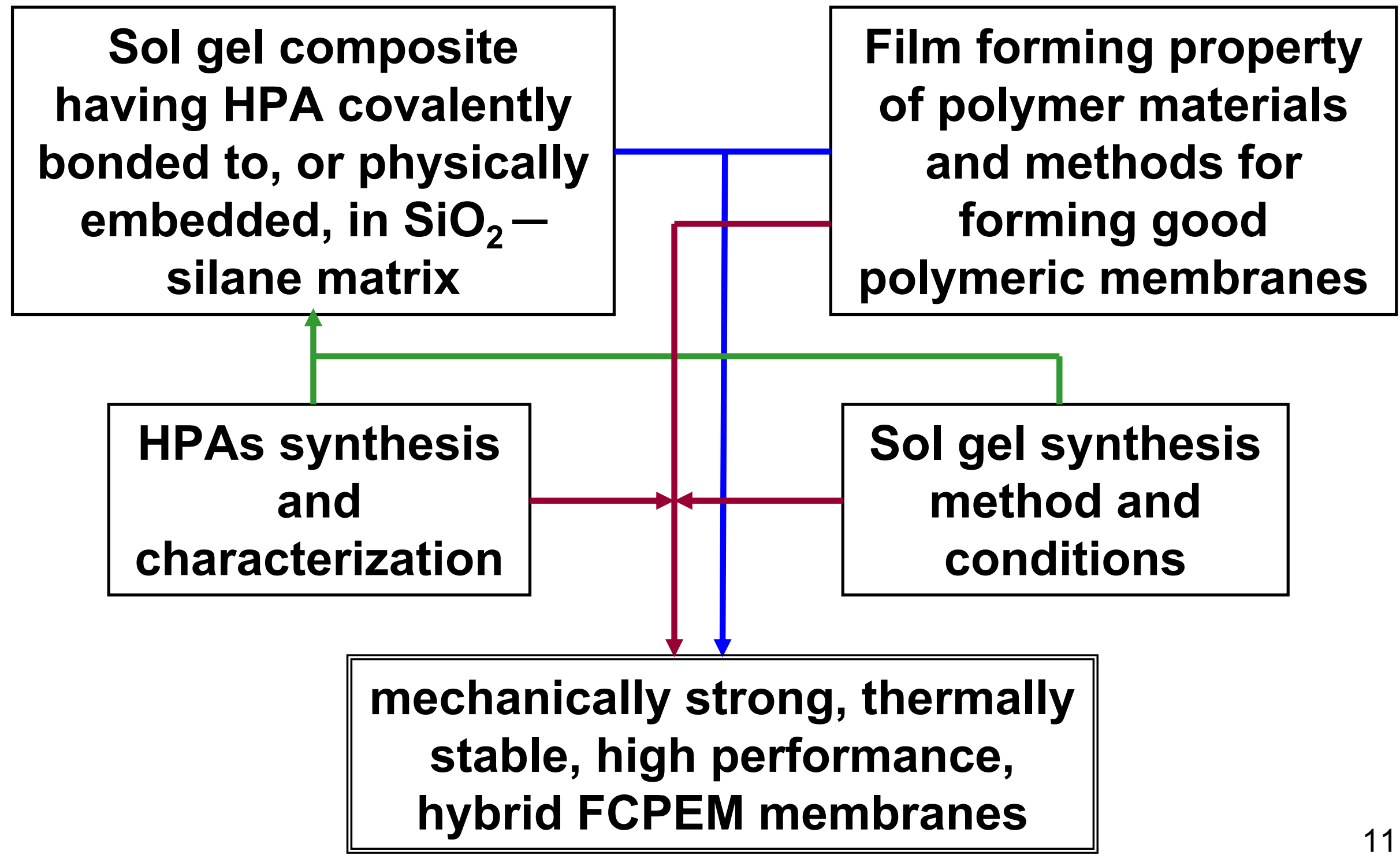


Polymerization Methods for immobilizing $\mathrm{H}^{+}$Carrier/Transmitter Composites

1. Post-Polymerization:

$\left(\mathrm{H}^{+}\right)$: proton donor

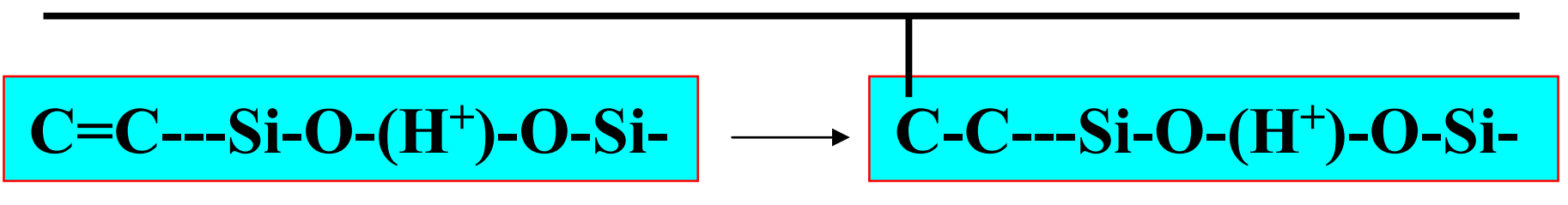

2. Pre-Polymerization

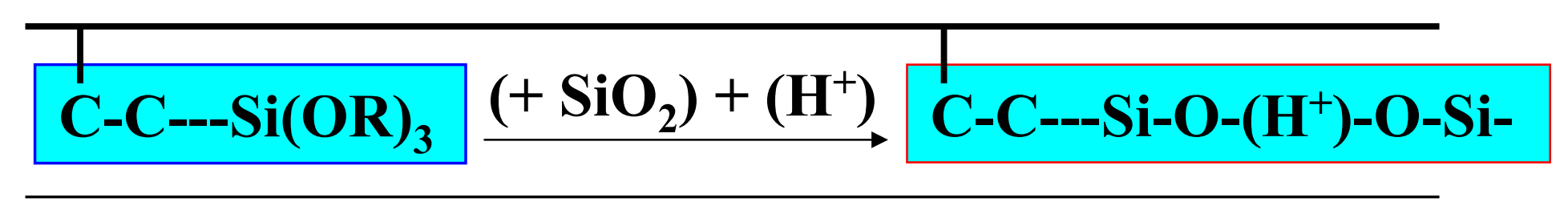

3. Co-Polymerization:

$$
\begin{aligned}
& \mathrm{C}=\mathrm{C}---\mathrm{Si}(\mathrm{OR})_{3}+\left(\mathrm{H}^{+}\right) \\
& \left(+\mathrm{SiO}_{2}\right)(+\mathrm{Modifier})
\end{aligned} \longrightarrow \begin{aligned}
& \mathrm{C}-\mathrm{C}---\mathrm{Si}-\mathrm{O}-\left(\mathrm{H}^{+}\right)-\mathrm{O}-\mathrm{Si}- \\
& \hline
\end{aligned}
$$

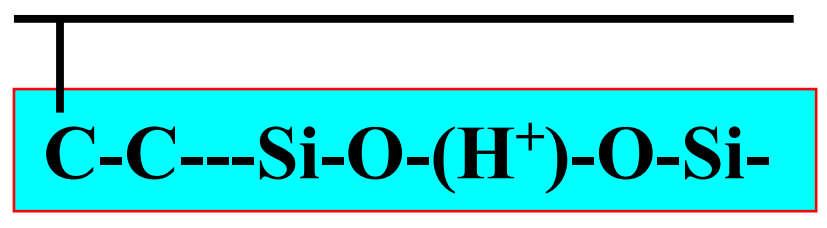




\section{Procedure for Fabricating Hybrid Composite PEM Membranes}

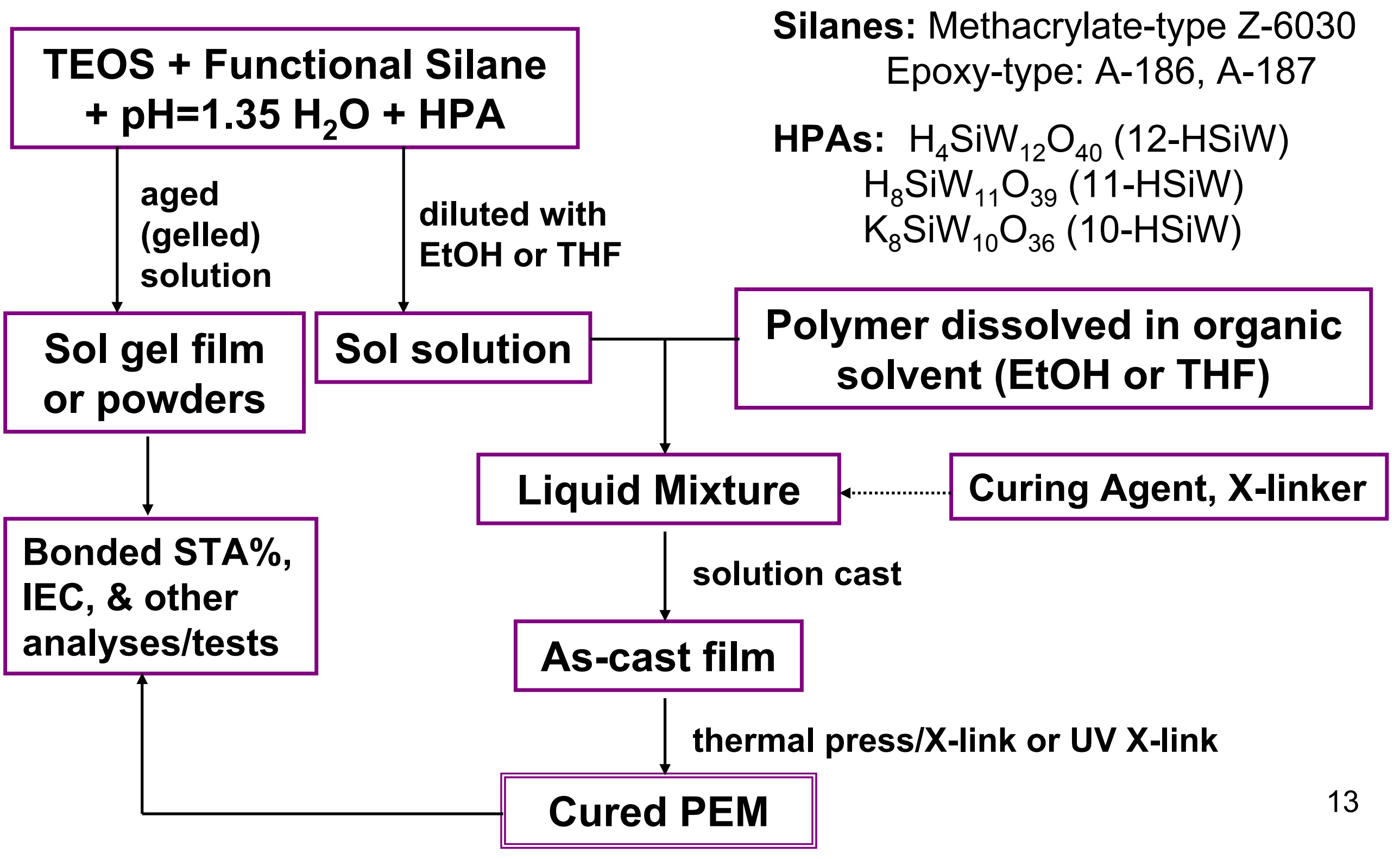




\section{"Bonding HPA": Sol Gel Composite (No Silane) $\rightarrow$ 12-HSiW Washed Off}

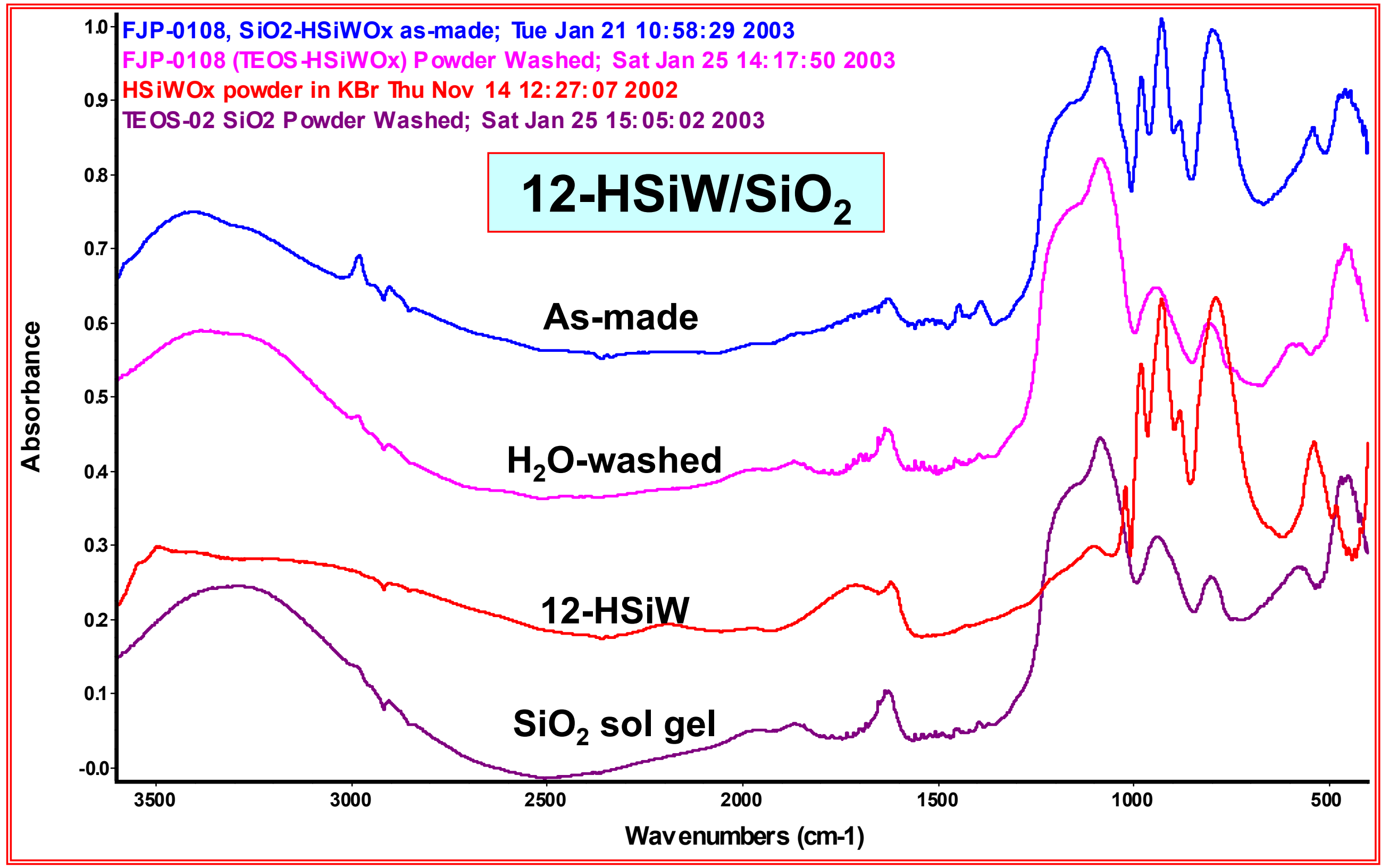




\section{"Bonding HPA": Sol Gel Composite (with Z-6030 silane) $\rightarrow$ 12-HSiW Retained}

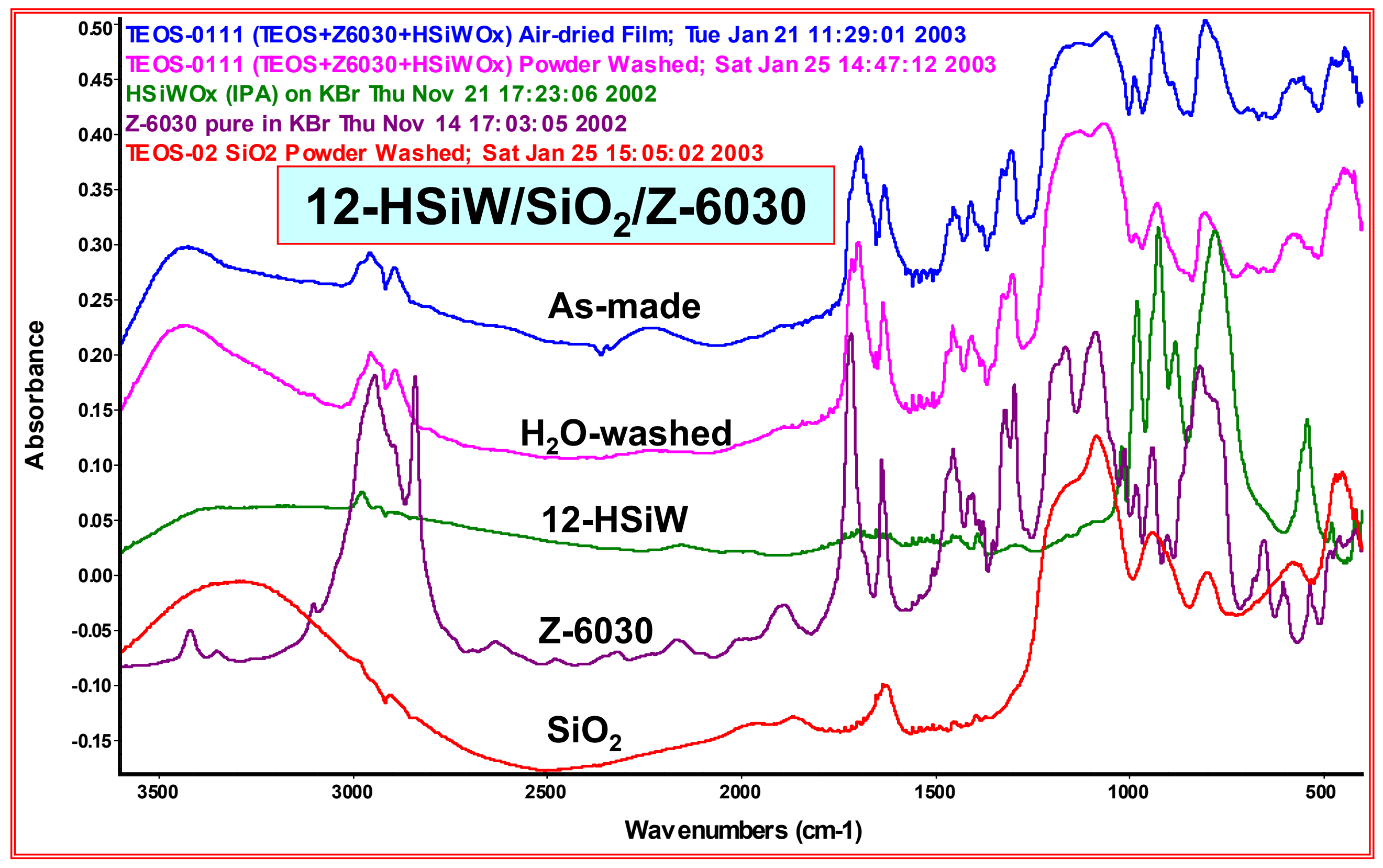




\section{HSiWxOy Bonded/Embedded to Silica/Silane Network and IEC of Sol Gel Composites}

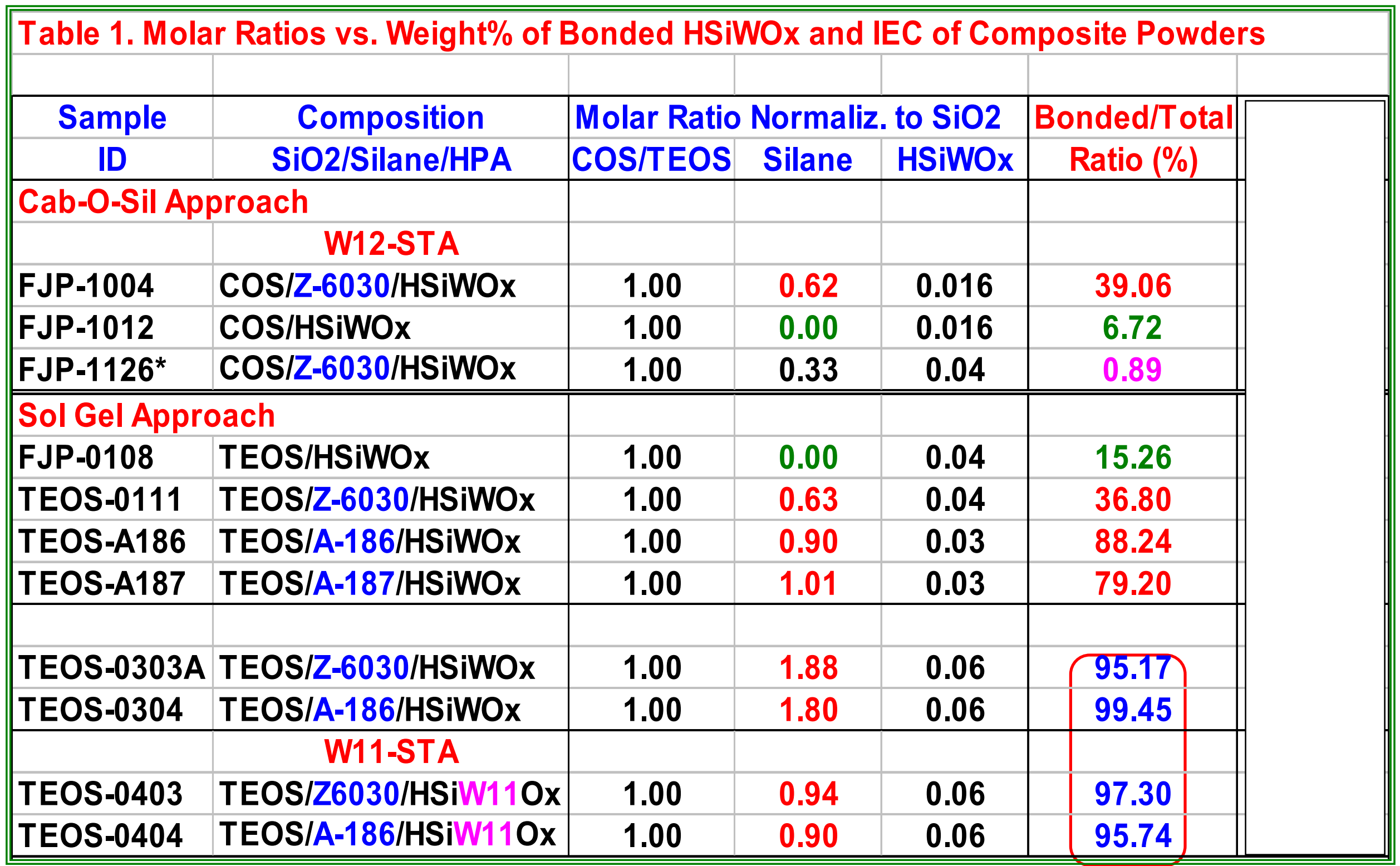

* Final solution $\mathrm{pH} 4$.3; all others $\mathrm{pH} \leq 1.0$. IEC are for $\mathrm{H}_{2} \mathrm{O}$-washed powders. 


\section{Water-retention capability of $\mathrm{SiO}_{2}, 12-\mathrm{HSiW}$,}

and two 12-HSiW/SiO $/ 2 /$ Silane sol gel composites (DSC Analysis)

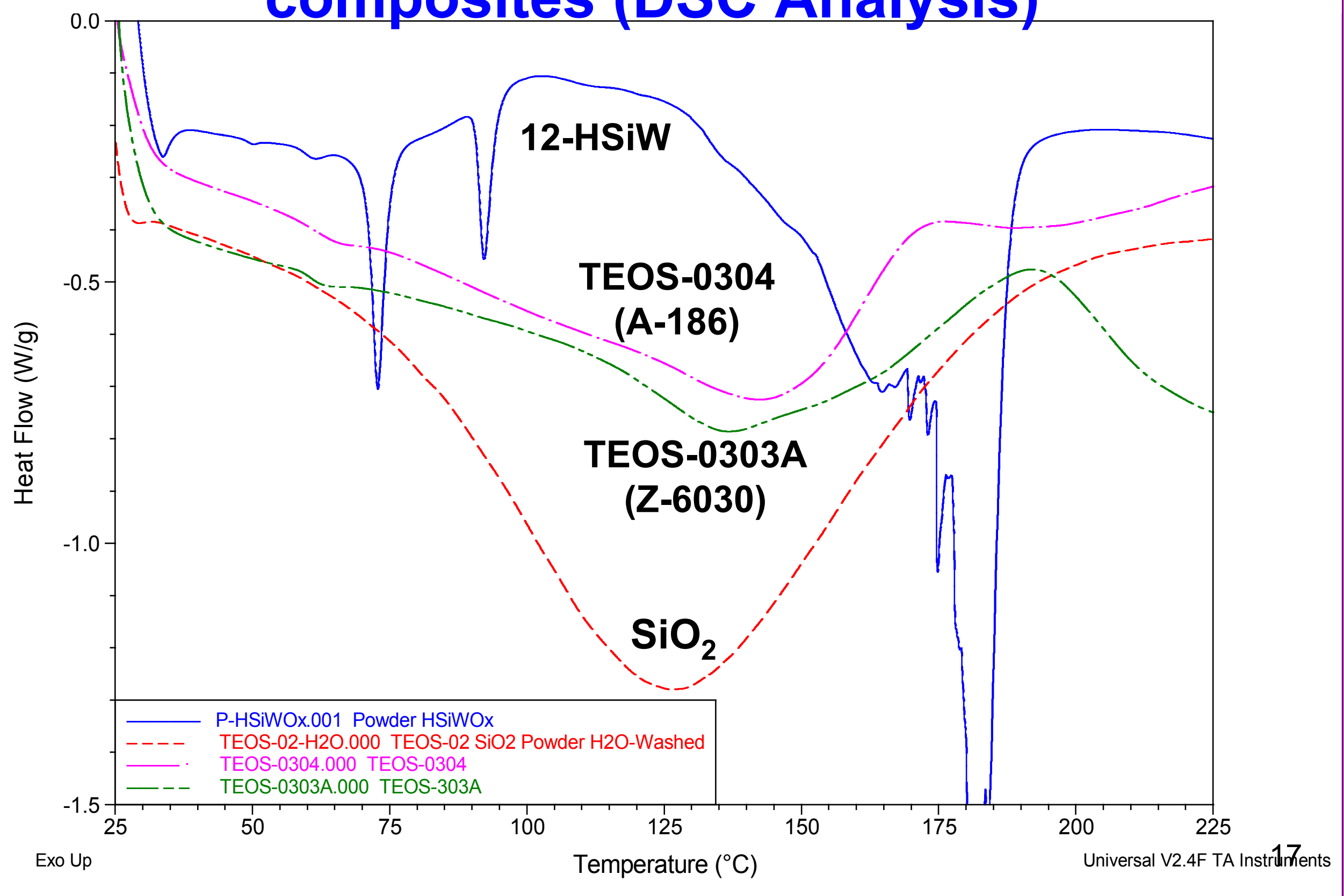




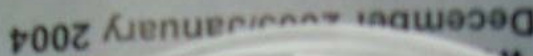

BSPPO: a specialty polypropylene oxide

\section{2-HSiW/BSPPO = $44 \mathrm{wt} \%$ $\mathrm{SiO}_{2} / \mathrm{BSPPO}=13.5 \mathrm{wt} \%$}

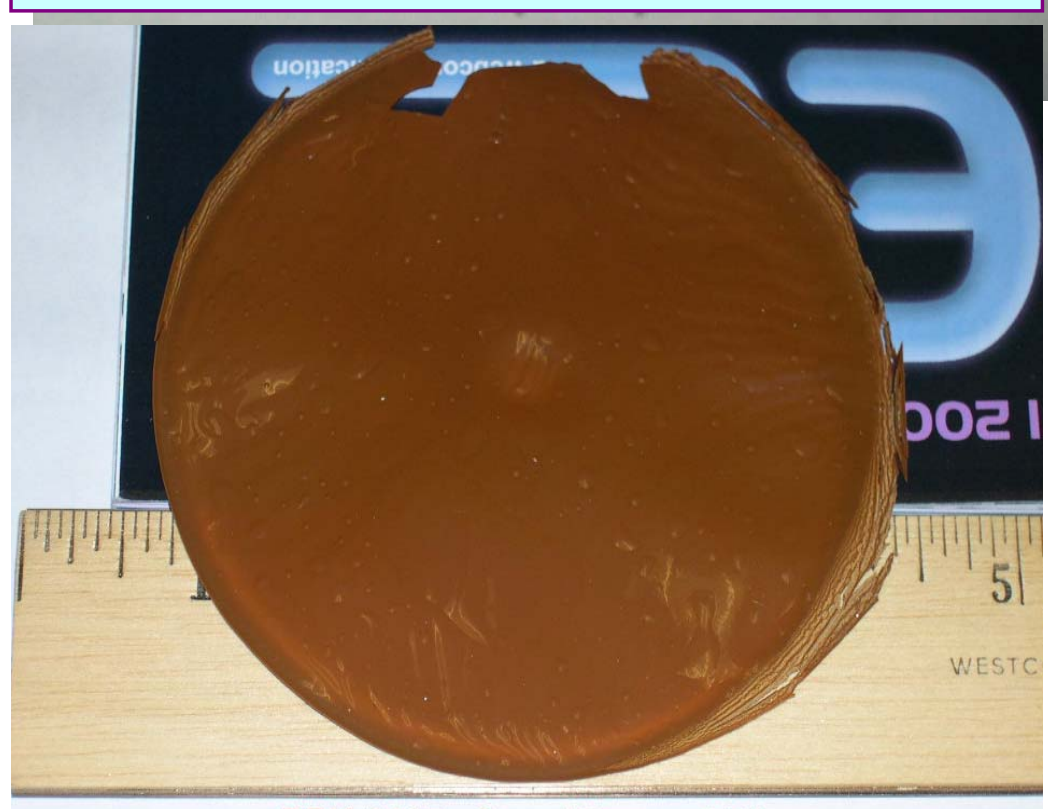

PEM-0105 Cured/Pressed Film
12-HSiW Sol Gel Composite/ BSPPO Hybrid PEM

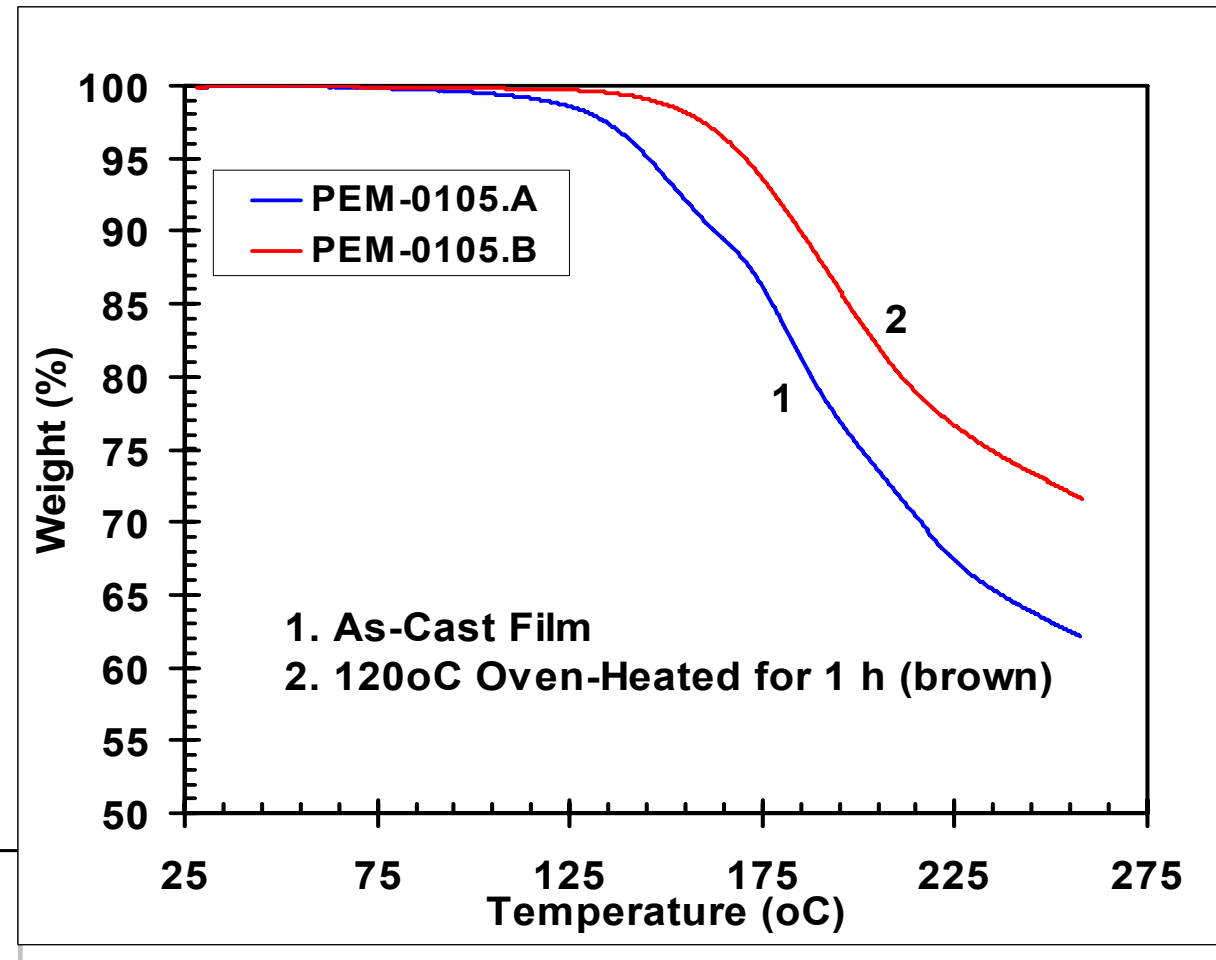

TGA-FTIR Analysis:

PEM-0105 Oven-heated at $120^{\circ} \mathrm{C}$ for $1 \mathrm{~h}$ $0.040-$
$0.035-$
$0.020-$
$0.015-$
$0.005-$
$0.000-$ 0.000

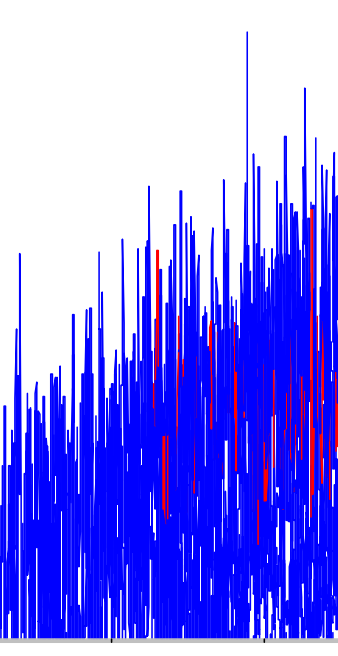

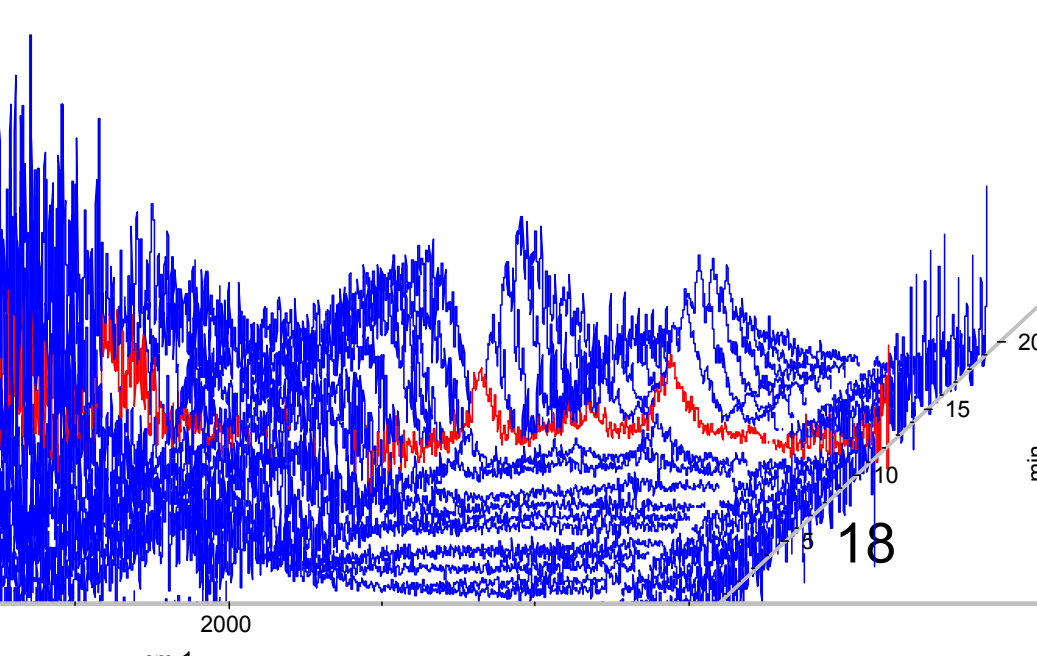




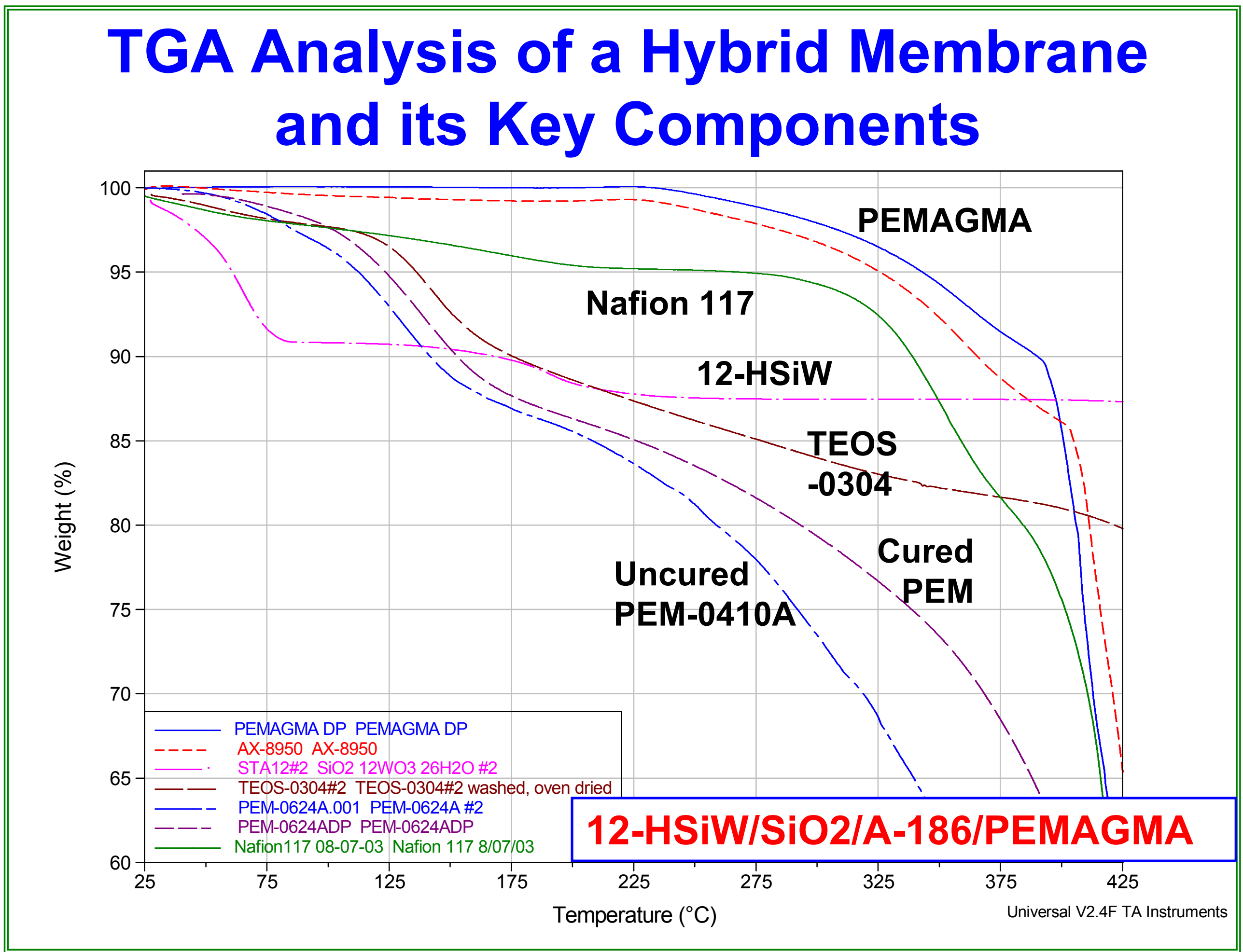




\section{Accomplishments/Progress - 1 - HPA and Doped Nafion ${ }^{\circledR}$}

- HPAs: A large number of HPAs based on the Keggin, Dawson, and more complex skeletons have been synthesized and their structural properties relevant to proton conduction elucidated by IR, NMR.

Thermal stability of all proton conducting phases determined by TGA.

- Proton diffusion properties are characterized by pulse field gradient spin echo NMR. Many HPA have high diffusion coefficients and low activation energies for diffusion.

- HPA /PVDF: HPA high proton conduction under dry conditions was demonstrated in a PVDF matrix.

- HPA Doped Nafion ${ }^{\circledR}:$ Nafion ${ }^{\circledR}$ was doped with various HPA which interact strongly with the $-\mathrm{SO}_{3} \mathrm{H}$ groups and in some cases dramatically improved proton diffusion.

- These doped Nafion ${ }^{\circledR}$ membranes were incorporated in MEAs and tested in a fuel cell, showing dramatic improvements at $120^{\circ} \mathrm{C}$, but as the HPA in these systems are not immobilized this may be a result of improvements to the membrane/electrode interface. 


\section{Accomplishments/Progress - 2}

-- PEM Fabrication and Performance

- $\mathrm{SiO}_{2}$ Sol Gel Composite-Polymer Hybrids:

- by simple mixing method

- by "Two-Step" method

- by direct copolymerization method

- various host polymers

- on-going work

- Sol-gel synthetic methods: Several are established for making HPA-containing sol gel composites with the functional silanes

- HPA-containing hybrid PEM membranes: Physical blending, two-step and direct copolymerization methods are developed.

- Analytical procedures are established for IEC, bleaching, structural, thermal stability analysis, electrical (conductivity), and fuel cell performance tests. 


\section{Summary}

- A variety of HPAs have been successfully synthesized, characterized, and used for PEM fabrications.

- A variety of methods for immobilizing HPAs in different polymer matrices have been successfully demonstrated:

- Physical blending/embedding

- Sol gel composite-polymer hybrid

- Flexible, cross-linked, high-STA-loading hybrid PEMs are obtained for the first time

- FC performance test results indicate the HPA-based PEMs are very promising for high-temp operations without the need of humidification. 


\section{Future Work}

- Understand the synergistic interaction of HPA with ionomers in terms of improving proton conduction at low humidity/elevated temperatures

- Continue to develop immobilization strategies and optimize hybrid HPA for proton conduction 


\section{Hydrogen Safety}

The most significant, potential hydrogen hazard associated with this project is fire and/or explosion due to either leak, ignition, or strong impact of the highly pressurized $\mathrm{H}_{2}$ gas cylinders, resulting in personnel injuries and/or loss of equipment in the laboratory. 


\section{Hydrogen Safety}

Our approach to deal with the potential hazard:

- A Standard Operating Procedure (SOP) has been implemented.

- All personnel involved in the use of compressed $\mathrm{H}_{2}$ cylinders are required to take pertinent ES\&H training at NREL and familiar with the SOP prior to being authorized for work.

- Personnel protective equipment (PPE) such as safety goggles or glasses are required when present in the lab. Wearing a face shield is required when changing the pressure regulator.

- The $\mathrm{H}_{2}$ cylinders are well secured and properly capped when not in use. NFPA warning labels (e.g., High Pressure Gas, Flammable Compressed $\mathrm{H}_{2}$ ) are attached to the cylinders. Valves are only opened to the necessary pressure.

- No hot work, open fire, and compressed $\mathrm{O}_{2}$ cylinders are allowed nearby the $\mathrm{H}_{2}$ cylinders or fuel cell test station.

- Regular check of leaking is conducted with soapy water solution.

- Fire extinguishers are available in the laboratory.

- Emergency response and exit are clearly stated in the SOP and also marked in the lab. 